\title{
Analisis Komposisi Fasa dan Parameter Unit Sel Kristal Hasil Kalsinasi Suhu Tinggi Abu Cangkang (Paguroidea) dengan Metode Rietveld
}

\author{
Amirul Mukminin ${ }^{1 *}$ \\ ${ }^{1}$ STT Migas Balikpapan \\ *E-mail: amirmin25@gmail.com
}

\begin{abstract}
Abstrak
Analisis kuantitatif dengan cara penghalusan data (refinement) metode Rietveld untuk sampel katalis berbasis unsur kalsium dari abu cangkang kelomang (Paguroidea) telah berhasil dilakukan. Hasil refinement menunjukan bahwa sampel abu cangkang kelomang yang dikalsinasi pada suhu $900^{\circ} \mathrm{C}$ memberikan perbedaan komposisi fasa dan parameter unit sel kristal karena pengaruh waktu kalsinasi 2, 3 dan 4 jam. 2 jam adalah fasa tunggal $\mathrm{CaCO}_{3}$ kalsit, 3 jam adalah multifasa $\mathrm{CaCO}_{3}$ kalsit dan $\mathrm{CaO}$, sedangkan sampel 4 jam merupakan fasa tunggal CaO. Nilai Reabilitas (R) hasil refinement, $R_{\mathrm{P}}, R_{\mathrm{wp}}, R_{\mathrm{exp}}$ dan $\mathrm{GoF}=\chi^{2}$ memberikan hasil yang baik dan dapat diterima.
\end{abstract}

Kata kunci : Katalis $\mathrm{CaO}$ dan $\mathrm{CaCO}_{3}$, x-ray diffraction, Rietveld Analisis

\begin{abstract}
Quantitative analysis by data refinement of the Rietveld method for calcium-based catalyst samples from hermit crabs (Paguroidea) ash has been successfully carried out. The results of the improvement showed that the samples of hermit crab shell calcined at $900{ }^{\circ} \mathrm{C}$ gave different phase compositions and unit cell parameters due to the influence of calcination times 2, 3 and 4 hours. 2 hours is a single phase CaCO3 calcite, 3 hours are multiphase $\mathrm{CaCO} 3$ calcite and $\mathrm{CaO}$, while a 4 hour sample is a single phase $\mathrm{CaO}$. The reliability value $(R)$ of the improvement results, $R_{P}, R_{w p}, R_{\text {exp }}$ and $G o F=\chi^{2}$ gives good and acceptable results.
\end{abstract}

Keywords : $\mathrm{CaO}$ and $\mathrm{CaCO}_{3}$ Catalyst, x-ray diffraction, Rietveld Anlysis

\section{Pendahuluan}

Pembuatan katalis basa yang mengandung unsur kalsium (Ca) seperti; cangkang telur, cangkang keong mas, cangkang kerang dan tulang hewan, biasanya dilakukan melalui kalsinasi pada suhu tinggi antara $500^{\circ} \mathrm{C}-900^{\circ} \mathrm{C}[1]$. Dalam proses ini Yoshioka [2] menjelaskan bahwa akan terjadi tranformasi fasa padatan yang diikuti perubahan bentuk kristal dari padatan dalam setiap satuan suhu yang digunakan. Pada suhu $500^{\circ} \mathrm{C}-900^{\circ} \mathrm{C}$ mineral $\mathrm{CaCO}_{3}$ terdapat dalam tiga fasa yaitu aragonit, kalsit, dan veterit dan puncak $\mathrm{CaO}$ sudah mulai muncul. Sedangkan pada suhu $900^{\circ} \mathrm{C}$ dengan waktu lebih dari 3 jam terbentuk $\mathrm{CaO}$ dengan keadaan yang lebih stabil.

Para peneliti umumnya mempelajari tranformasi fasa padatan kristal dengan mencocokan difraktogram sinar-X dengan dengan data standar (JCPDS database) untuk mempelajari perubahan tersebut. Namun metode ini hanya bersifat kualitatif dan kurang mampu menunjukkan perubahan secara tepat tentang keseluruhan tranformasinya hingga tingkat parameter unit sel kristalnya.

Solusi untuk mempelajari secara detail mengenai perubahan fasa kristal ini hingga pada bagian paramater unit sel dapat dilakukan 
dengan memanfaatkan perhitungan Metode Rietveld. Metode ini merupakan metode penghalusan data (refinement) yang diperkenalkan oleh Hugo Rietveld sekitar tahun 1960-an. Cara ini bertujuan untuk keperluan karakterisasi material kristal.

Dalam analisis Rietveld dilakukan panghalusan (refinement) parameter-parameter sebuah model yang disusun berdasarkan interpretasi struktur kristal untuk dicocokan dengan data terukur sehingga tercapai nilai selisih kuadrat minimal. Metode Rietveld memiliki kemampuan analisis data keluaran XRD dengan mencocokkan lebih dari 1 fasa yang ada sekaligus dan mampu mengidentifikasi fasa yang saling bertumpukkan (overlapping) [3].

Parameter keluaran dari software Retica untuk analisis kuantitatif (metode Rietveld) berupa komposisi fasa serta perhitungan masing-masing parameter unit sel kristal. Beberapa peneliti telah berhasil melaporkan pemanfaat metode ini dalam penelitian mereka [4], [5],[6]. Selain itu, laporan Metode Rietveld tentang transformasi fasa dan parameter unit sel kristal dari katalis berbasis unsur Ca dari abu cangkang kelomang (Paguroidea) belum banyak dilaporkan. Oleh karena itu, pada penelitian ini akan dipelajari tentang seluruh komposisi dan parameter unit sel kristal dari sampel abu cangkang kelomang yang dikalsinasi pada suhu $900^{\circ} \mathrm{C}$ dengan perbedaan waktu kalsinasi 2, 3, dan 4 jam.

\section{Metoda Penelitian}

\subsection{Pengumpulan Data}

Penelitian ini dilaksanakan di

Laboratorium Kimia STT Migas Balikpapan dan Laboratorium Kimia Laboratorium Sentral Mineral dan Material Maju FMIPA Universitas Negeri Malang. Instrumen penelitian adalah seperangkat komputer dengan software Rietica, ICSD database; $\mathrm{CaO}, \mathrm{CaCO}_{3}$ kalsit dan $\mathrm{CaCO}_{3}$ vetiret, dan data difraksi sinar-X serbuk (XRD). Data XRD masing-masing sampel berupa abu cangkang kelomang yang dikalsinasi pada suhu $900^{\circ} \mathrm{C}$ masing-masing selama 2, 3, dan 4 jam. Perekaman data seluruh sampel menggunakan XRD serbuk (PHILIPS-binary) dengan radiasi $\mathrm{Cu}-\mathrm{K} \alpha=1,54060 \AA$, tegangan $30 \mathrm{~mA}$ dan $40 \mathrm{kV}$ sudut operasi $2 \theta 10^{\circ}-89,9^{\circ}$, scan step $0,017^{\circ}$ dan waktu 10,15 detik. Penentuan keadaan fasa tunggal atau multifasa difraktogram XRD setiap sampel dipelajari dengan software Match! versi 2.4.7.

\subsection{Analisis Kuantitatif Metode Rietveld}

Analisis kuantitatif metode Rietveld dengan software Rietica for Windows 1.7.7 dilakukan untuk memperoleh kesesuaian antara data pengamatan dan perhitungan. Metode Rietveld adalah suatu metode pencocokan antara kurva teoritis yaitu database kristalografi yang dipilih dari data (ICSD database) dengan kurva eksperimen (observasi) hingga kedua kurva memiliki kesesuaian seluruhnya. Kurva observasi merupakan suatu difraktogram yang terdiri atas sudut difraksi (2 $\theta$ ) dengan intensitasnya yang di dapatkan dari alat difraksi sinar-X (XRD). Kurva teoritas (kalkulasi) adalah kurva kalkulasi yang didapatkan dari hasil analisis metode Rietveld. Kesesuaian ke dua kurva diusahakan dengan metode kuadrat terkecil (least square) yang dilakukan secara berulangulang (iterasi) sehingga terdapat kecocokan antara ke dua kurva yang berarti terdapat kecocokan antara data yang diamati dengan data kalkulasi [5].

Secara matematis prinsip dasar dari metode Rietveld adalah untuk meminimalisir fungsi $M$ yang merupakan selisih dari profil yang dikalkulasi $\left(\mathrm{y}^{\text {calc }}\right)$ dengan data pengamatan $\left(\mathrm{y}^{\mathrm{obs}}\right)$.

$M=\sum_{i} w_{i}\left\{y_{i}^{o b s}-\frac{1}{c} y_{i}^{c a l}\right\}$

Dimana $w_{i}$ adalah bobot statistik dan $c$ adalah faktor skala, $\mathrm{y}^{\text {calc }}=$ cy $^{\text {obs }}$

Keberhasilan proses penghalusan (refinement) dapat dilihat dari nilai indeks kecocokan, yakni Error seminimal mungkin 
yang dinyatakan dengan indeks $R$ seperti $R_{\text {wp }}$ (indeks kecocokan bobot), $R_{\exp }$ (asumsi pembilang membawa nilai yang diharapkan), $R_{\mathrm{P}}$ (merupakan indeks kecocokan seluruh hasil fitting tidak ikut mempertimbangkan faktor bobot statistik $w_{\mathrm{i}}$ ), dan Goodness Of Fitting $(\mathrm{GoF})=\chi^{2}$ (chi-square goodness fit). merupakan indeks pencocokan yang menunjukkan sukses atau tidaknya penghalusan.

$$
\begin{aligned}
& R_{w p}=\left\{\frac{\sum_{i} w_{i}\left(y_{i}^{o b s}-y_{i}^{c a l}\right)^{2}}{\sum_{i} w_{i}\left(y_{i}^{o b s}\right)^{2}}\right\}^{1 / 2} \ldots \ldots \ldots \ldots \\
& R_{\text {exp }}=\left\{\frac{N-P+C}{\sum_{i} w_{i}\left(y_{i}^{o b s}\right)^{2}}\right\}^{1 / 2} \ldots \ldots \ldots \ldots \ldots \ldots .
\end{aligned}
$$

Dimana $N$ adalah jumlah pengukuran, $P$ adalah jumlah parameter refinement, dan $C$ adalah jumlah konstrain yang digunakan dalam refinement.

$$
\begin{gathered}
R_{p}=\frac{\sum\left|y_{i}^{o b s}-y_{i}^{c a l}\right|}{\sum y_{i}^{o b s}} . \\
G o F=\frac{R_{w p}}{R_{\exp }} \ldots \ldots \ldots \ldots .
\end{gathered}
$$

Proses penghalusan data (Refine) dalam Rietica memerlukan data masukan (input file) yang berisi tentang Histograms, Phases, parameter sel kristal dengan ekstensi inp, sedangkan data kedua adalah data sudut $2 \theta$ dan intensitas difraksi sinar-X dengan ekstensi .dat atau .xy. Jika input parameter yang diisi sudah benar maka akan muncul pola difraksi pada layar monitor dan akan menampilkan nilai $\mathrm{Rp}$, Rwp, dan GOF ( $\left.\chi^{2}\right)[6]$

Parameter yang di refine adalah background, parameter sel (a, b dan c), faktor skala (scale factor), space group, komponen pelebaran $U$ dan $H_{L}$, peak shape function yang dipilih adalah Voigt dengan Howard asymmetry dan preferred Oriented, dari masing-masing atom. Parameter asimetri sendiri telah digunakan oleh Rietveld untuk menghasilkan puncak seperti pada dimana dengan penambahan parameter asimetri puncak kalkulasi lebih mendekati data pengukuran dibanding profil Gaussian murni. [7].

\section{Hasil Penelitian}

Analisis fasa menggunakan software Match! versi 2.4.7, menunjukkan bahwa difraktogram sinar- $\mathrm{X}$ abu cangkang kelomang yang dikalsinasi pada $900^{\circ} \mathrm{C}$ dengan waktu 2 jam memiliki fasa tunggal $\mathrm{CaCO}_{3}$ kalsit dan sampel 4 jam juga fasa tungal $\mathrm{CaO}$ murni. Hanya untuk sampel 3 jam terjadi dua fasa yaitu $\mathrm{CaCO}_{3}$ kalsit dan $\mathrm{CaO}$ dengan intensitas rendah. Keseluruhan standar yang akan dikalkulasi (ICSD database) ditampil pada Tabel 1 dan 2 berikut ini:

Tabel 1. Data ICSD parameter unit sel kristal

\begin{tabular}{ccccccc}
\hline Fasa & Space & \multicolumn{2}{c}{ Kisi } & \multicolumn{2}{c}{ Sudut } & $\mathbf{Z}$ \\
& Group & $\mathbf{a}=\mathbf{b}$ & $\mathbf{c}$ & $\boldsymbol{\alpha}=\boldsymbol{\beta}$ & $\mathbf{y}$ & \\
\hline $\mathrm{CaCO}_{3}$ & R-3C & 5.051 & 17.3 & 90 & 120 & 6 \\
$\mathrm{CaO}$ & FM3M & 4.89 & 4.89 & 90 & 90 & 4 \\
\hline
\end{tabular}

Tabel 2. Data ICSD parameter atom kristal

\begin{tabular}{ccccccc}
\hline Fasa & Atom & $\mathbf{x}$ & $\mathbf{y}$ & $\mathbf{z}$ & $\mathbf{B}$ & $\mathbf{n}$ \\
\hline $\mathrm{CaCO}_{3}$ & $\mathrm{Ca}$ & 0.000 & 0.000 & 0.000 & 1.00 & 0.167 \\
& $\mathrm{C}$ & 0.000 & 0.000 & 0.250 & 1.00 & 0.167 \\
& $\mathrm{O}$ & 0.0000 & 0.257 & 0.250 & 1.00 & 0.500 \\
$\mathrm{CaO}$ & $\mathrm{Ca}$ & 0.000 & 0.000 & 0.500 & 1.00 & 0.0208 \\
& $\mathrm{O}$ & 0.000 & 0.000 & 0.000 & 1.00 & 0.0208 \\
\hline
\end{tabular}

Gambar 1 menunjukan hasil Analisis kuantitatif metode Rietveld dengan software Rietica for Windows 1.7.7 dari sampel 2 dan 4 jam dilakukan refinement metode Rietveld fasa tunggal, sedangkan sampel 3 jam menggunakan metode multifasa. Pola difraksi hasil refinement seluruh sampel menunjukan kesesuaian nilai antara intensitas puncak kalkulasi $\left(\mathrm{y}^{\text {calc }}\right.$ ) garis hitam ('+') dari standar data ICSD (Tabel 1) dengan intensitas puncak data XRD hasil observasi ( $\mathrm{y}^{\mathrm{obs}}$ ) garis merah. Kesesuaian tersebut menunjukkan bahwa data intensitas pengamatan dan perhitungan memiliki faktor skala yang tepat[3], [8]. 


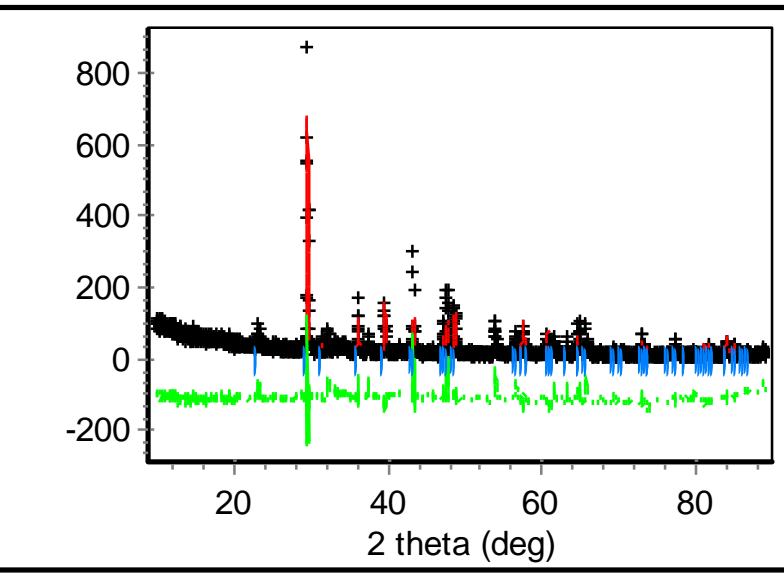

(a)

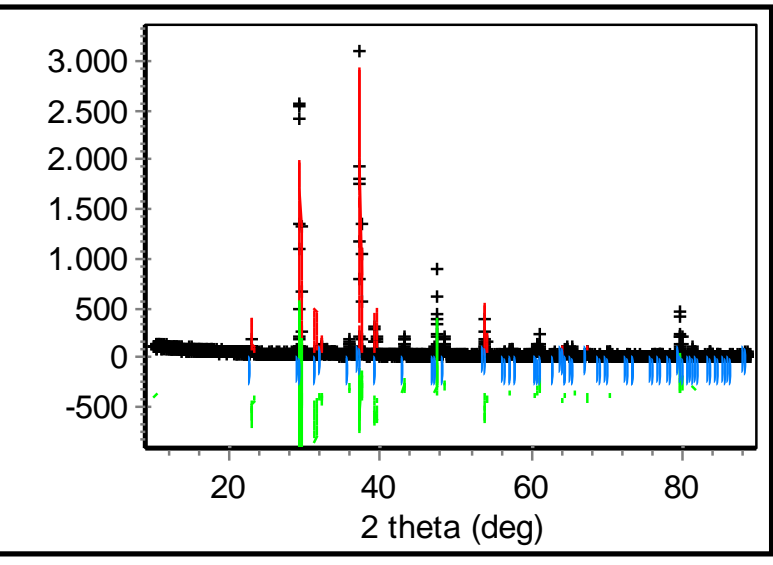

(b)

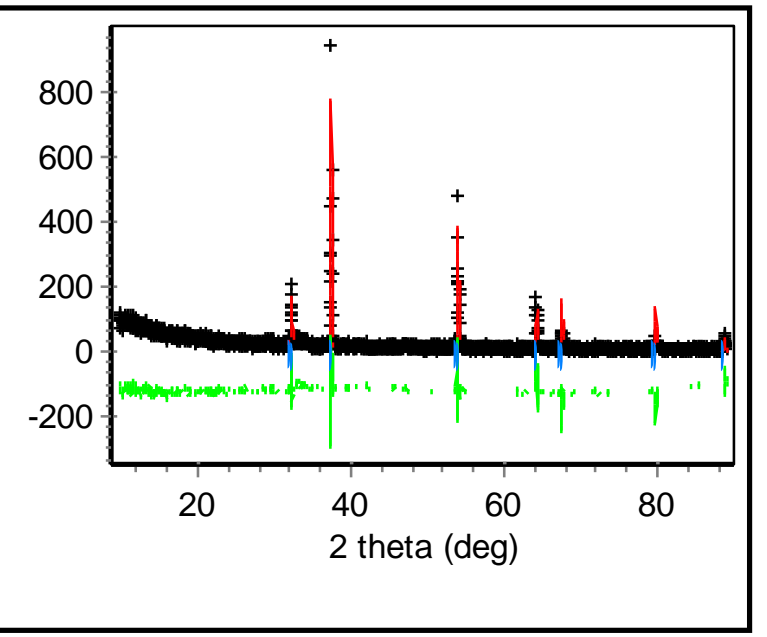

(c)

Gambar 1. Hasil refinement sampel difraktogram abu cangkang kelomang pada suhu $900^{\circ} \mathrm{C}$ dengan waktu pemanasan masing-masing (a) 2 jam, (b) 3 jam, dan (c) 4 jam
Pada sampel 3 jam di sudut $80^{\circ}$ terlihat adanya ketediksesuaian puncak profil yang dikalkulasi $\left(\mathrm{y}^{\mathrm{calc}}\right.$ ) dengan data pengamatan $\left(\mathrm{y}^{\mathrm{obs}}\right)$ yang menunjukkan adanya pembentukan fasa lain yang merupakan puncak baru $\mathrm{CaO}$. Kondisi ini menyebabkan nilai Reabilitas (R) hasil refinement yaitu $R_{\mathrm{P}}, R_{\mathrm{wp}}, R_{\exp }$ dan $\mathrm{GoF}=$ $\chi^{2}$ lebih tinggi jika dibandingkan dengan hasil refinement sampel 2 jam dan 4 jam. Hasil lengkap dapat dilihat pada Tabel. 3.

\begin{tabular}{ccccc}
\multicolumn{5}{c}{ Tabel 3.Nilai Reabilitas (R) hasil refinement } \\
\hline $\begin{array}{c}\text { Sampel } \\
\text { (jam) }\end{array}$ & $\begin{array}{l}R_{\mathrm{P}} \\
(\boldsymbol{\%})\end{array}$ & $\begin{array}{l}R_{\mathrm{wp}} \\
(\boldsymbol{\%})\end{array}$ & $\begin{array}{c}R_{\exp } \\
(\boldsymbol{\%})\end{array}$ & $\mathrm{GoF}\left(\chi^{2}\right)$ \\
\hline 2 & 27.56 & 18.22 & 43.04 & 0.18 \\
3 & 41.19 & 33.93 & 19.48 & 0.30 \\
4 & 30.89 & 18.56 & 45.65 & 0.16 \\
\hline
\end{tabular}

Lebih lanjut, Tabel 3 menunjukkan bahwa refinement Rietveld dapat diterima menurut kriteria yang disyaratkan yaitu GoF < 4\% dan Rwp < 20\%[9]. Dengan demikian, parameter-parameter hasil penghasulan layak untuk yang diekstrak dan dapat dianalisis lebih lanjut. Tingginya nilai $\mathrm{R}_{\mathrm{wp}} 33.93 \%$ untuk sampel 3 jam masih dapat diterima karena nilai GoF masih menunjukan nilai 0.3 $\%$.

Transformasi fasa $\mathrm{CaCO}_{3}$ kalsit menjadi $\mathrm{CaO}$ pada sampel 3 jam dapat difahami sebagai penyebab tingginya nilai $\mathrm{R}_{\mathrm{wp}}$. Keadaan fasa padatan adalah mutlifasa tidak seperti sampel 2 jam dan 4 jam yang fasa tunggal. Refinement difraktogram multifasa, nilai $\mathrm{R}_{\exp }$ tidak dapat dijadika acuan dalam menentukan keabsahan dan ketepatan ekspektasi penentuan model struktur, karena pasti terdapat tumpang tindih antar puncak antar fasa. Oleh karena itu, dalam menentukan keabsahan dan penerimaan hasil refinement dari difraktogram multifasa, parameter residu yang dijadikan acuan hanya $\mathrm{R}_{\mathrm{p}}, \mathrm{R}_{\mathrm{wp}}$ dan GoF saja[5].

Hasil refinement untuk perbandingan parameter unit kisi sel kristal (a, b, c, volume sel dan space grup) dengan data standar masing-masing sampel ditunjukan pada Tabel 4. 
Tabel 4. Nilai Parameter Unit sel kristal hasil refinement

\begin{tabular}{|c|c|c|c|c|c|c|}
\hline \multirow[t]{2}{*}{ Sampel } & \multirow{2}{*}{$\begin{array}{l}\text { Space } \\
\text { Group }\end{array}$} & \multicolumn{2}{|c|}{ Kisi (Å) } & \multicolumn{2}{|c|}{ 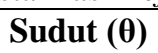 } & \multirow{2}{*}{$\begin{array}{c}\text { Vol Sel } \\
\left(\AA^{3}\right)\end{array}$} \\
\hline & & $\mathbf{a}=\mathbf{b}$ & c & $\alpha=1$ & $y$ & \\
\hline$* \mathrm{Ca}$ & D $3 C$ & 5.051 & & 90 & 120 & 382.368 \\
\hline${ }^{*} \mathrm{CaO}$ & $\mathrm{F}$ & & 4. & 90 & 9 & \\
\hline $2 \mathrm{ja}$ & $\mathrm{R}$ & 4.997 & $17 .(1$ & 90 & 120 & 31 \\
\hline \multirow[t]{2}{*}{3 jam } & $\mathrm{R}$ & ) & 17. & 90 & 12 & \\
\hline & & 4.8 & 4.8 & 90 & 90 & \\
\hline 4 jam & $\mathrm{Fm} 3 \mathrm{~m}$ & 4.819 & 4.819 & 90 & 90 & 111.960 \\
\hline
\end{tabular}

*ICSD database

Berdasarkan Tabel 4 diatas semua sampel menunjukan penururunan rata-rata parameter kisi $(a, b, c)$ sel kristal sekitar $1 \%$ sedangkan untuk volume sel sebesar $3 \%$. Perbandingan parameter sel menunjukkan bahwa kesesuaian preparasi sampel dan hasil identifikasi struktur dengan model standar memiliki struktur yang sama yakni fasa tunggal $\mathrm{CaCO}_{3}$ kalsit dengan grup ruang (space grup) R-3C untuk sampel 2 jam. Sampel 3 jam adalah padatan multifasa yaitu $\mathrm{CaCO}_{3}$ kalsit dengan grup ruang R-3C dan Fm3m , sedangkan sampel 4 jam merupakan padatan $\mathrm{CaO}$ dengan space grup $\mathrm{Fm} 3 \mathrm{~m}$. Kesesuaian parameter kisi (lattice parameter) tersebut mengindikasikan koordinat atom, ukuran partikel dan okupansi yang sama.

\section{Kesimpulan}

Hasil penghalusan data (refinement) analisis kuantitatif metode Rietveld telah mampu memberikan gambaran komposisi fasa dan parameter unit sel kristal semua sampel cangkang kelomang yang dikalsinasi pada suhu $900^{\circ} \mathrm{C}$ dengan variasi waktu kalsinasi masing-masing 2, 3 dan 4 jam.

Seluruh data refinement menunjukan kesusain yang baik antara data intensitas puncak kalkulasi ( $\mathrm{y}^{\text {calc }}$ ) ICSD database dengan intensitas puncak data XRD hasil observasi $\left(\mathrm{y}^{\mathrm{obs}}\right)$. Kesesuaian tersebut menunjukkan bahwa data intensitas pengamatan dan perhitungan memiliki faktor skala yang tepat. Sampel 2 jam adalah fasa tunggal padatan $\mathrm{CaCO}_{3}$ kalsit, 3 jam adalah padatan multifasa $\mathrm{CaCO}_{3}$ kalsit dan $\mathrm{CaO}$, sedangkan sampel 4 jam merupakan padatan fasa tunggal $\mathrm{CaO}$.

\section{Saran}

Diperlukan adanya penelitian lebih lanjut analisis kuantitatif metode Rietveld dengan memperhatikan perubahan nilai Reabilitas (R) hasil refinement yaitu $R_{\mathrm{P}}, R_{\mathrm{wp}}, R_{\exp }$ dan $\mathrm{GoF}$ dalam setiap pengukuran background, parameter sel (a, b dan c), faktor skala (scale factor), space group, komponen pelebaran $U$ dan $H_{L}$, peak shape function yang dipilih adalah Voigt dengan Howard asymmetry dan preferred Oriented, dari masing-masing atom secara bertahap.

\section{Daftar Pustaka}

[1] J. Boro, A. J. Thakur, and D. Deka, "Solid oxide derived from waste shells of Turbonilla striatula as a renewable catalyst for biodiesel production," Fuel Process. Technol., vol. 92, no. 10, pp. 2061-2067, 2011.

[2] S. Yoshioka and Y. Kitano, "Transformation of aragonite to calcite through heating," Geochem. J., vol. 19, no. 4, pp. 245-249, 1985.

[3] R. A. Young, The rietveld method, vol. 5. International union of crystallography, 1993.

[4] S. Sembiring, "Analisis Kuantitatif Data Diffraksi Sinar X Fasa Keramik Crystoballite Berbasis Silika Sekam Padi dengan Metode Rietveld," JIEMS (Journal Ind. Eng. Manag. Syst., vol. 3, no. 2, 2017.

[5] R. A. Shobirin and R. T. Tjahjanto, "Pengembangan Teknik Analisis Pola Difraksi Multifasa dengan Metode Rietveld Refinement : Studi Kasus Lapis Tipis PZT," vol. 4, no. 1, pp. 23-30, 2017.

[6] S. Pratapa, "Pengaruh Jangkau Sudut Ukur Pada Hasil Analisis Data Difraksi Sinar-X Menggunakan Metode Rietveld: Kasus Campuran Mgo-Y2o3,” Makara J. Sci., 2010.

[7] B. A. Hunter and C. J. Howard, "LHPM: a computer program for Rietveld analysis of Xray and neutron powder diffraction patterns," ANSTO Rep., 1998.

[8] H. Rietveld, "A profile refinement method for nuclear and magnetic structures," J. Appl. Crystallogr., vol. 2, no. 2, pp. 65-71, 1969.

[9] E. H. Kisi and C. J. Howard, Applications of neutron powder diffraction, vol. 15. Oxford University Press, 2012. 